\title{
Communication Strategies Used by Pre-Service English Teachers of Different Proficiency Levels
}

\section{Estrategias comunicativas utilizadas por profesores de inglés en formación con diferentes niveles de proficiencia*}

\author{
Angela Yicely Castro Garcés \\ angelayicely@gmail.com
Silvio Fabián López Olivera ariados26@hotmail.com
Universidad del Tolima, Colombia

This paper reports on the findings of a research study carried out in the Bachelor of Arts in English program of study at a Colombian university. It aims at identifying the communication strategies used by four pre-service English teachers with A2 and B2 levels of language proficiency and, also, at examining how these communication strategies facilitate or hinder the development of communicative skills. Data collection instruments included audio recordings of three tasks: (1) open-ended questionnaire, (2) sentence translation, and (3) picture description. The participants' speech was transcribed and categorized allowing us to identify and examine the role played by communication strategies which varied depending on the choice the participants made of using either avoidance or compensatory strategies.

Key words: Communicative skills, communication strategies, pre-service English teachers

En este artículo se reportan hallazgos de una investigación realizada en la Licenciatura en Inglés de una universidad colombiana. Sus objetivos fueron identificar las estrategias comunicativas usadas por cuatro docentes de inglés en formación con niveles de lengua A2 y B2 y examinar cómo éstas facilitan o dificultan el desarrollo de habilidades comunicativas. Los instrumentos de recolección de datos incluyeron grabaciones de tres tareas: (1) cuestionario, (2) traducción y (3) descripción de imágenes. Se transcribieron y categorizaron las intervenciones orales de los participantes, lo que permitió identificar y examinar el papel jugado por las estrategias comunicativas, el cual dependió de la elección hecha por los participantes de usar estrategias evasivas o de compensación.

Palabras clave: docentes de inglés en formación, estrategias comunicativas, habilidades comunicativas

* Received: October 17, 2013. Accepted: February 2, 2014. 


\section{Introduction}

The development of language skills in learners and the decision of what English teachers should concentrate on in lesson planning and classroom instruction comprise a recurrent discussion in our field. Therefore, the communicative goal of language teaching keeps its relevance as more students are interested in and required to use the language as a communicative tool. In fact, during the last four decades, there has been a significant amount of research to find strategies that can help learners communicate more effectively in a foreign language. Bialystok (1990) defines communication strategies (CS) as "a systematic technique employed by a speaker to express his meaning when faced with some difficulty" (p. 3). Dörnyei (1995) proposes a list of thirteen CS, which we analyze in this study. He includes two avoidance and 11 compensatory strategies.

Research is closer to the language classroom every day as English teachers have understood the need to keep up-to-date and to improve their teaching practices. This study has a qualitative approach and reflects that continuous search for qualifying our teaching. The participants involved are four students from the B.A. in English program at Universidad del Tolima (Colombia) who, in spite of being in eighth semester, have different proficiency levels-A2 and B2, according to the Common European Framework of Reference and were determined through the IELTS test scores. This study allowed us to analyze the CS used by these students and how these CS facilitate or hinder the development of communicative skills. In order to trigger the use of CS the following three tasks were presented to students: (1) open-ended questionnaire, with twelve questions in English, (2) sentence translation, with ten statements in Spanish to be translated into English, and (3) picture description, with six images to be described (See Appendix). Students' speech was recorded and afterwards narrowly transcribed, categorized, and analyzed in search of CS. The interview was designed considering what Labov (1972) calls the observer's paradox, "the effort to find out how people talk when they are not being systematically observed" (p. 209). The data were analyzed in terms of the frequency of CS strategies used by counting the number of occurrences of each strategy and analyzing if the strategies varied depending on the students' language proficiency level.

As a result, the data seemed to point out that the CS used by learners varied depending on the task, the moment of interaction, the communicative goal, and the proficiency level.

\section{Theoretical Framework}

In language teaching, as well as in the broader educational community, a strong distinction has often been made between academic research and classroom practice (Burns, 1999). Academic research conventions have created a separation between theory, research, 
and practice (Hopkins, 2008). Different authors support the idea that many teachers regard research with suspicion, at best; and with contempt, at worst, as the province of academic researchers who know little_ and understand less_-about the day-to-day business of life in the language classroom (Beasley \& Riordan, 1981; McDonough \& McDonough, 1990). The facts described by the assertions above, as well as our experience as English teachers-who are tailors of our own classroom practices and conscious that there are standards that guide us and standardized tests that frame us_-are good reasons to make us reflective practitioners, that is, teachers who are always in search for innovation and bringing research and practice closer together for the benefit of the learner.

\section{Developing Communication Skills in Second Language Learning}

Windle and Warren (2013) mention the use of language in order to communicate and to connect with other people. Nevertheless, the act of communicating may pose linguistic and social barriers which can hinder communication. Windle and Warren also acknowledge the existence of three essential components of communication: verbal (the words we choose), nonverbal (how we say the words) and paraverbal (our body language). They state that they are needed in order to send clear and concise messages and to receive and correctly understand messages sent to us. Therefore, when it comes to second language learning, the necessity to gain communicative skills becomes not only a linguistic, but also a social need that requires being aware of the environment and of the culture that comprise part of the target language.

In regard to the development of speaking skills, Thornbury (2005) states that "speaking is interactive and requires the ability to co-operate in the management of speaking turns. It also typically takes place in real time, with little time for detailed planning and represents a real challenge to most language learners" (p. iv).

When analyzing learners' communicative skills, it becomes essential to bear in mind the kind of learners we have and the context they are immersed in. Brown (2007) reflects on the factors that may affect language learning and teaching. He includes age, psychological, sociocultural, and linguistic factors. Some relevant issues to take into account in each factor are: (a) in age factors: the critical period hypothesis, the significance of accent, cognitive, and affective considerations; (b) in psychological factors: styles and strategies and personality factors; (c) in sociocultural factors: communicative competence, culture, and attitudes; and (d) in linguistic factors: the contrastive analysis hypothesis, interlingua transfer, and communication strategies. We consider that Brown's position as to what it takes to learn a language is an essential consideration as a learning variable in order to be respectful and inclusive when teaching a second/foreign language. Brown (2001) states that 
proficiency levels are ambiguous entities difficult to measure. He affirms that teachers will differ among themselves on what the terms "beginners," "intermediate," or "advanced" mean; however, there is a standard set of guidelines that offer a practical description of the different skills that second/foreign language learners are expected to achieve. Those guidelines provide proficiency standards for test makers; in this way, it is acceptable to classify learners based on test results, which is one of the main variables that we have taken into account in this study.

\section{Communication Strategies}

Strategy researchers became influential in the 1970's when language learning theory was moving away from the behaviorist theory towards more social theories of learning. It was not until Hymes (1972) claimed that effective performance was determined not only by linguistics (linguistic universals or grammar rules) but also by knowledge of the appropriate use of the rules in a particular social context that language started to be studied as a social phenomenon. These last four decades have been marked by the urge of finding strategies to help learners communicate more effectively in a foreign language and different terms for CS have been coined. As a result, a variety of authors (Bialystok, 1990; Bialystok \& Kellerman, 1987; Dörnyei, 1995; Kasper \& Kellerman, 1997; Selinker, 1972; Tarone, 1981; Thornbury, 2005; Varadi, 1980) have listed and defined different CS.

Bialystok (1990) cites two definitions related to the strategies of second language learners that are complementary to each other: (1) "a systematic technique employed by a speaker to express his meaning when faced with some difficulty, and (2) techniques of coping with difficulties in communicating in an imperfectly known second language" (p. 3). Those definitions illustrate what communication strategies are actually for-to solve a communication problem and to help get a message across. Given that in second language learning learners will encounter communication problems usually caused by a lack of linguistic resources, CS may help them overcome these problems so that they can convey their intended meaning. The lists of communication strategies that appear in the literature range from eight proposed by Thornbury (2005) to 13 proposed by Dörnyei (1995).

We consider Dörnyei's (1995) list to be more inclusive because it takes into account many more strategies that are present in speakers' utterances which are not included in the other lists, such as literal translation and stalling or time gaining strategies; at the same time he gives a name to the strategies that denote that long silent period (long pause) that speakers have when they have nothing to say about a topic and prefer to switch topics, usually because of lack of linguistic resources; those are avoidance strategies. Table 1 shows the list presented by Dörnyei with its definitions and examples. 
Table 1. Communication Strategies Proposed by Dörnyei (1995)

\section{Avoidance strategies}

1. Message abandonment: Leaving a message unfinished because of language difficulties.

2. Topic avoidance: Avoiding topic areas or concepts that pose language difficulties.

\section{Compensatory Strategies}

3. Circumlocution: Describing or exemplifying the target object of action (e.g. the thing you open wine bottles with for corkscrew).

4. Approximation: Using an alternative term which expresses the meaning of the target lexical item as closely as possible (e.g. ship for sailboat).

5. Use of all-purpose words: Extending a general, empty lexical item to contexts where specific words are lacking (e.g. the overuse of thing, stuff, what-do-you call-it, thingy).

6. Word coinage: Creating a nonexistent second language (L2) word based on a supposed rule (e.g. vegetarianist for vegetarian).

7. Prefabricated patterns: Using memorized stock phrases, usually for "survival" purposes (e.g. Where is the ? or Comment allez vous? where the morphological components are not known to the learner).

8. Nonlinguistic signals: Mime, gesture, facial expression, or sound imitation.

9. Literal translation: Literally translating a lexical item, idiom, compound word, or structure from the native language (L1) to L2.

10. Foreignizing: Using an L1 word by adjusting it to the L2 phonology (i.e. with an L2 pronunciation) and/or morphology (e.g. adding an L2 suffix to it).

11. Code-switching: Using an L1 word with L1 pronunciation or an L3 word with L3 pronunciation while speaking in L2.

12. Appealing for help: Asking for aid from the interlocutor either directly (e.g. What do you call...?) or indirectly (e.g. rising intonation, pause, eye contact, puzzled expression).

13. Stalling or time-gaining strategies: Using fillers or hesitation devices to fill pauses and to gain time to think (e.g. well, now, let's see, uh, as a matter of fact).

Furthermore, Zhang (2007) reviews the different CS existent in foreign language learning and mentions that training students on its use can facilitate their communication process. Besides, O'Malley and Chamot (1990) assert that "CS are particularly important in negotiating meaning where either linguistic structures or sociolinguistic rules are not shared between a second language learner and a speaker of the target language" (p. 43). 


\section{Method}

This research study has a qualitative approach and intends to analyze in detail each participant's use of communication strategies.

\section{Research Questions}

This study sought to answer two questions: (1) What are the communication strategies used by pre-service English teachers with different proficiency levels? and (2) How do the communication strategies used by pre-service English teachers facilitate or hinder the development of communicative skills?

\section{Description of the Context}

This study was conducted in a university course called Advanced Conversation offered to pre-service English teachers of the B.A. in English program at Universidad del Tolima. This is an undergraduate program developed in ten semesters. Advanced Conversation is a sixteen-week course that students take in eighth semester. The main objective of the course was to develop communication skills that allowed students to face different communication situations and monitor their discourse taking into account the moment of interaction and the interlocutor. Analyzing the use of CS during this study could shed light on the role these strategies play in the development of communication skills.

\section{Subjects}

Four pre-service teachers from eighth semester in the B.A. in English program at Universidad del Tolima participated in the study. The four students were chosen based on their score obtained on the IELTS test. Given that the IELTS scores obtained by all the students ranged from A2 to B2 in the Common European Framework of Reference, we decided to analyze the cases of the students who got the highest and lowest scores.

When students reached the eighth semester, they had already studied nearly 800 hours of English language in the classroom, plus 1,600 additional hours they were expected to study outside the classroom with the credit system that rules the program. In this way, they were expected to have reached a B2 level of language proficiency. It is also important to mention that this course had 21 students registered. This study was carried out by the homeroom teacher accompanied by a lead student who was also part of the class.

\section{Instruments}

Audio recordings of three tasks presented to students comprised the data collection instruments used. Each participant was interviewed and audio recorded; this interaction was 
impromptu, due to the fact that they did not have time to prepare the answers in advance. The questions for the interview were divided into three categories: (1) open-ended questionnaire, with twelve questions in English; (2) sentence translation, with ten statements in Spanish to be translated into English; and (3) picture description, with six images to be described. These audio recordings were afterwards narrowly transcribed - marking pauses, repetitions, laughs, and so on; then categorized and analyzed in search of CS. We also took notes of nonlinguistic signals while the participants answered the different tasks. The first 12 questions asked for personal experiences based on Labov's (1972) assertions that the elicitation of narratives of personal experience has proved to be the most effective among the partial solutions to the paradox of the face-to-face interview. In the second task, each student had to translate ten sentences. The sentences contained some words and structures that were likely to cause problems for students at this level of study. Flyman (1997), who carried out a study on the role CS play in the maintenance of communication in a classroom, proposed translation tasks to motivate the use of CS, since these give rise to the highest number of compensatory strategies.

Regarding image description, Poulisse (1990) states that "concrete picture description tasks have been widely used in both first and second language acquisition research" (p. 68). In order to elicit CS from speech production, many kinds of reference tasks have been used in CS studies. Bialystock (1990) made use of the same kind of tasks to elicit CS used by learners of French in describing a color illustration to a French speaker to reconstruct the picture. Tarone (1981) also used a set of visual stimuli presented on a video screen for the speakers to describe or narrate what is shown; then the listeners had to choose the objects or pictures being described. What all these studies have in common is the use of real-world objects for which the vocabulary was unknown to the participants, thus creating lexical gaps in their communication processes and prompting the use of CS.

\section{Categories for Data Analysis}

The four participants were divided into two pairs, the A2 pair and the B2 pair, depending on their level of language proficiency. After having transcribed the information, we categorized their speech in terms of the frequency of use of the thirteen CS proposed by Dörnyei (1995).

\section{Data Analysis and Results}

This section presents the analysis of the data gathered and the implications of the CS used in the participants' communicative goals. ${ }^{1}$

1 Each participant was given a code as follows: S1A2 = Student 1 with A2 level, S2A2 = Student 2 with A2 level, S1B2 = Student 1 with B2 level, S2B2 = Student 2 with B2 level 
Tables 2 and 3 exemplify the frequency of use of the thirteen CS proposed by Dörnyei (1995). Additionally, the analysis shows the CS mostly used by each speaker.

Table 2. Number of CS Per Task

\begin{tabular}{||l|c|c|c|c|c|c|c||}
\hline \multicolumn{1}{|c|}{ Participant } & S1A2 & S2A2 & $\begin{array}{c}\text { Total } \\
\text { A2 }\end{array}$ & S1B2 & S2B2 & $\begin{array}{c}\text { Total } \\
\text { B2 }\end{array}$ & All \\
\hline $\begin{array}{l}\text { Task 1: open-ended } \\
\text { questionnaire }\end{array}$ & 43 & 34 & 77 & 63 & 52 & 115 & 192 \\
\hline $\begin{array}{l}\text { Task 2: sentence } \\
\text { translation }\end{array}$ & 19 & 28 & 47 & 22 & 12 & 34 & 81 \\
\hline $\begin{array}{l}\text { Task 3: picture } \\
\text { description }\end{array}$ & 23 & 42 & 65 & 27 & 16 & 43 & 108 \\
\hline Total & 85 & 104 & 189 & 112 & 80 & 192 & 381 \\
\hline
\end{tabular}

The four participants had a total of 381 occurrences of the thirteenth CS (see Table 2). The frequency and the choice of use of CS varied depending on the task. That is to say that Task 1 (open-ended questionnaire) motivated a higher use of CS with 192 occurrences, followed by Task 3 (picture description) with 108 occurrences and Task 2 (sentence translation) with 81 occurrences. Figure 1 illustrates the percentage of use of CS per task.

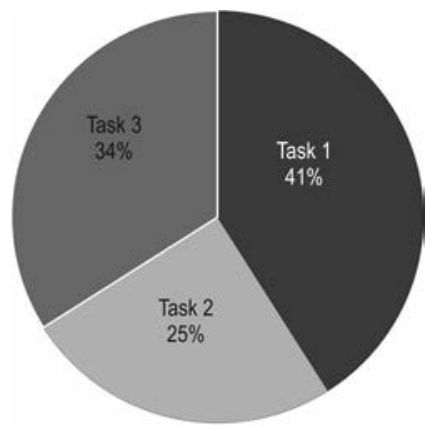

Figure 1. Percentage of CS per Task 
Certainly, open-ended questions gave participants the possibility to speak about personal experiences which, according to Labov (1972), reduces the effects of observation to a minimum and gives the speaker freedom to structure his discourse, including temporal organization, orientation, and coda. In that case, it seems that the topic and task presented to a speaker influenced the level of fluency to face the task and was associated with the CS needed to fill gaps, mark transitions, or appeal for help. The translation task was very structured, giving the participants specific instructions on what was expected and limiting their possibilities to use different language patterns.

Comparing the frequency of use of CS of A2 and B2 participants (A2 and B2 hereafter) on Task 1, it is evident that B2 use CS more frequently, which correlates with the long and elaborate answers they provided to the questions being asked compared with A2. For instance, in Task 1, Question 5, the participants were asked to talk about a moment when they were in danger. These were their answers:

S1A2: uhm....in danger? One night after class, I was...uhm walk on the street and they uhm they stole my thing. I was in danger. That was dangerous. Uhm no more. (The dots exemplify pauses. This participant had a 4 second pause, then a 2 second pause.)

S2A2: ehh when my grandmother ehh died? was dangerous? so dangerous so and that was the dangerous situation in my life maybe because...the feeling or that's the ... (This participant abandoned the message. This is shown with the three spaced dots.)

S1B2: Ok aeeeh? like a month and a half ago my grandma fell down it was something really really shocking because eeh I was about to to go to the university and she fell down and I heard a scream so I went there and she was on the floor. I tried to lift her up and she was... her head was... it was a shocking situation, but fortunately we went to the doctor and it was just a a little scratch; it was not so important or a damage in her head, it was just a scratch and she is ok now.

S2B2: uhm let me think...not my life in danger but my father's. Mm it was like two months ago? yeah? We had to take him to the emergency room because he had a a respiratory problem. I mean it was... difficult for us because it was the first time that my father was in danger...so well my mother was... her life was in danger long time ago but that time I I didn't feel...nervous but this time was different because I feel I felt I felt ah very nervous. 
Table 3. Number of CS per Level and Task

\begin{tabular}{|c|c|c|c|c|c|c|c|c|c|}
\hline \multirow{2}{*}{ Task } & \multicolumn{3}{|c|}{ S2A2 } & \multirow{2}{*}{$\begin{array}{c}\text { Total } \\
\text { A2 }\end{array}$} & \multicolumn{3}{|c|}{ S2B2 } & \multirow{2}{*}{$\begin{array}{c}\text { Total } \\
\text { B2 }\end{array}$} & \multirow{2}{*}{ All } \\
\hline & 1 & 2 & 3 & & 1 & 2 & 3 & & \\
\hline \multicolumn{10}{|c|}{ Avoidance strategies } \\
\hline $\begin{array}{l}\text { Message } \\
\text { abandonment }\end{array}$ & 10 & 8 & 8 & 26 & 5 & 2 & & 7 & 35 \\
\hline Topic avoidance & 3 & 2 & & 5 & 2 & & & 2 & 7 \\
\hline \multicolumn{10}{|c|}{ Compensatory strategies } \\
\hline Circumlocution & 1 & 2 & & 3 & & & & & 3 \\
\hline Approximation & 1 & 1 & & 2 & 1 & 1 & 1 & 4 & 6 \\
\hline $\begin{array}{l}\text { Use of all-purpose } \\
\text { words }\end{array}$ & 2 & & 1 & 3 & 1 & 4 & 1 & 6 & 9 \\
\hline Word coinage & 5 & & 2 & 7 & & & & & 7 \\
\hline $\begin{array}{l}\text { Prefabricated } \\
\text { patterns }\end{array}$ & 14 & 2 & 13 & 29 & 14 & & 6 & 20 & 49 \\
\hline $\begin{array}{l}\text { Nonlinguistic } \\
\text { signals }\end{array}$ & 2 & 3 & 5 & 10 & & 3 & 14 & 17 & 27 \\
\hline Literal translation & 2 & 9 & 1 & 12 & 3 & 1 & 1 & 5 & 17 \\
\hline Code-switching & 1 & 2 & 3 & 6 & & & & & 6 \\
\hline Appealing for help & 9 & 5 & 13 & 27 & 9 & 4 & 6 & 19 & 46 \\
\hline $\begin{array}{l}\text { Stalling or time- } \\
\text { gaining strategies }\end{array}$ & 28 & 13 & 19 & 60 & 70 & 19 & 13 & 102 & 162 \\
\hline
\end{tabular}

Table 3 presents the frequency of use of CS and compares the ones used by A2 and B2.

Message abandonment. It occurred 26 times on A2 and 7 times on B2. These CS do not help the speaker pursue his communicative goals; they are, instead, used as a signal of lack of linguistic resources.

but but I have another...and maybe in this ... 
study alone is good because... or sometimes in group ...

Topic avoidance. Just as message abandonment, it shows lack of linguistic resources and evidences the speakers' fear to even start talking about a specific topic because it poses language difficulties. This one was present 5 times in A2 and 2 times in B2: "Uhm...I don't know," "there is no, nooo."

Circumlocution. It occurred only 3 times in A2 with the following examples:

Uhm...there is a tree, there are animals, yes, uhm...these animals go meee (to mean sheep).

The man was... he was showing cell phones on a thing you use to sell, to show things (to mean a big jacket with inner pockets).

Approximation. It was used 4 times by B2 and 2 times by A2.

It's like an analysis (to mean a book review).

The lady, she has a bag (to mean a purse).

It seems that B2 find approximation to be a better resource than circumlocution which, although similar to the former, evidences more limited linguistic resources in the speakers who use it.

Use of all-purpose words. It was used 6 times by B2 and 3 times by A2: "They stole my things," "But if it is a project or something like that."

Word coinage. It was only used by A2 and had 7 occurrences: domit - omit, scientic scientific

Prefabricated patterns. From the 29 used by A2 and the 20 used by B 2 it was observed that all of them used the same recurrent prefabricated patterns. Some of these patterns overlapped with time gaining strategies: "well," "let me think."

Non-linguistic signals. Mostly used by B2 with 17 occurrences as compared with 10 occurrences present in A2 speech. It seems to be a way to help the conversation flow more smoothly and to increase understanding. Nevertheless, they were sometimes used to try to get the message across when there was limited vocabulary (pointing to an object in a picture, snapping fingers).

Literal translation. It was present in all participants' speech, with 12 occurrences in A2 and 5 in B2. Literal translation is more likely to be used by speakers with a low proficiency level and avoided as speakers gain more language proficiency.

Please come back the keys (instead of please return the keys).

By the present I invite you to my party (instead of I hereby invite you to my party).

Foreignizing. It did not occur in any of the participants' utterances. We anticipated the translation task to be a trigger for this type of CS, but it did not happen. 
Code-switching. A2 code-switched 6 times but there were no occurrences in B2. This happened mostly in tasks 2 and 3 where they were expected to use some specific vocabulary. Code switching frequently overlapped with appealing for help.

Uhm...I don't know to say seguridad [security].

If I...was...uhm...se me olvidó como se llama eso [I forgot how that's called].

Appealing for help. Occurred 27 times in A2 and 19 in B2; it was a widely used form of CS. A2 appealed for help with expressions such as:

The dog is...uhm...I don't remember the word

I feel eh...what's the word?

B2, on the other hand, appealed for help asking for approval or waiting for the interviewer to backchannel rather than explicitly asking for help.

Because I don't believe in that kind of of...uhm superstition?

He was a philologist, right?

Stalling or time-gaining strategy. With 162 occurrences in all, it was the most widely used of the CS. B2 used it 102 times and A2 used it 60 times. Stalling or time gaining seems to be a strategy that helps communication flow, especially for $\mathrm{B} 2$ who made a smart use of this strategy to fill gaps very resourcefully; these gaps would have otherwise looked like empty spaces or choppy sentences. There was gap filling in B2 with expressions such as: well, you know. There was stalling, rather than gap filling, in A2 with long pauses up to 7 seconds.

\section{Conclusions}

This study revealed the CS used by pre-service English teachers with different proficiency levels and shed some light on how these CS facilitate or hinder the development of communicative skills, to wit: (1) The subjects studied used both avoidance and compensatory CS; (2) the CS used varied depending on the task, the moment of interaction, the communicative goal, and the proficiency level; (3) B2 use of CS helped the flow of conversation allowing learners to achieve their communicative goals, while A2 use of CS frequently hindered communication because of the CS choice-avoidance and time gaining strategies, including long pauses-(4) Stalling or time gaining was the most used type of CS with slight differences in use depending on the proficiency level - that is, B2 used it as strategic gap fillers while its use in A2 seemed to reveal a lack of linguistic resources.

Given the results presented above, learners should be encouraged to replace avoidance strategies with compensatory strategies such as circumlocution, approximation, and time gaining strategies, and, as they gain more linguistic resources, learners should avoid the 
overuse of all-purpose words, word coinage, prefabricated patterns, literal translation, and code-switching. As a result, a good choice in the use of CS by language learners can be of great help to facilitate the development of communicative skills.

\section{References}

Beasley, B., \& Riordan, L. (1981). The classroom teacher as researcher. English in Australia, 55, $36-41$.

Bialystok, E. (1990). Communication strategies: A psychological analysis of second language use. London, UK: Blackwell.

Bialystok, E., \& Kellerman, E. (1987). Language strategies in the classroom. In B. K. Das (Ed.), Communication and learning in the classroom community (6 ${ }^{\text {th }}$ ed., pp. 160-175). Singapore, SG: SEAMEO Regional Language Center.

Brown, H. D. (2001). Teaching by principles: An interactive approach to language pedagogy (2nd ed.). White Plains, NY: Pearson Education.

Brown, H. D. (2007). Principles of language learning and teaching. White Plains, NY: Pearson Education.

Burns, A. (1999). Collaborative action research for English language teachers. Cambridge, UK: Cambridge University Press.

Dörnyei, Z. (1995). On the teachability of communication strategies. TESOL Quarterly, 29(1), 55-85.

Flyman, A. (1997). Communication strategies in French as a foreign language. Working Papers, 46, 57-73.

Hymes, D. H. (1972). On communicative competence. In J. B. Pride \& J. Holmes (Eds.), Sociolinguistics: selected readings (pp. 269-293). Harmondsworth, UK: Penguin.

Hopkins, D. (2008). A teacher's guide to classroom research (4th ed.). Maidenhead, UK: McGrawHill/Open University Press.

Kasper, G., \& Kellerman, E., (Eds.). (1997). Communication strategies: Psycholinguistics and sociolinguistic perspectives. London, UK: Longman.

Labov, W. (1972). Sociolinguistic patterns. Oxford, UK: Blackwell.

McDonough, J., \& McDonough, S. (1990). What's the use of research? ELT Journal, 44(2), 102-109.

O’Malley, J. M., \& Chamot, A. U. (1990). Learning strategies in second language acquisition. Cambridge, UK: Cambridge University Press.

Poulisse, N. (1990). The use of compensatory strategies by Dutch learners of English. Dordrecht, NL: Foris Publications.

Selinker, L. (1972). Interlanguage. International Review of Applied Linguistics in Language Teaching, 10(3), 209-231.

Tarone, E. (1981). Some thoughts on the notion of communication strategy. TESOL Quarterly, 15(3), 285-295.

Thornbury, S. (2005). How to teach speaking. Harlow, UK: Pearson Education Limited. 
Varadi, T. (1980). Strategies of target language learner communication: Message adjustment. International Review of Applied Linguistics, 6, 71-90.

Windle, R., \& Warren, S. (2013). Communication skills. Retrieved from http:// www.directionservice. org/cadre/section4.cfm

Zhang, Y. (2007). Communication strategies and foreign language learning. US-China Foreign Language, 5(4), 43-48.

\section{The Authors}

Angela Yicely Castro Garcés holds a B.A. in Modern Languages, a specialization in Pedagogy of Reading and Writing, and an M.A. in TESOL. She is an associate teacher in the B.A. program in English at Universidad del Tolima, Colombia.

Silvio Fabián López Olivera is a tenth semester student in the B.A. in English program at Universidad del Tolima, Colombia. He works as an English teacher at the Language Center of the same university. 


\section{Appendix: Tasks Developed in the Project}

\section{Task 1: Open-ended questionnaire}

1. What is your level of English according to the CEFR in each language skill?

2. What skill have you developed most and why?

3. What do you do to improve your English?

4. How often do you practice English?

5. Think of a moment that was special for you; a happy moment, event, or situation. Tell me the story.

6. Think of a moment when you were in danger. How was it? What happened?

7. What do you think of the curriculum of the B.A. in English program? Has it met your expectations? Would you add or omit any subject? Why?

8. Talk about a person who has inspired you. Describe the person and explain why you find him/her inspirational.

9. What's your favorite book or movie? Describe it and say why it is your favorite.

10. What custom from your home country are you most fond of? Describe the custom and explain why you like it.

11. Would you like to live in a big city or a small town? Why?

12. In your opinion, is it better to study alone or with friends? Why?

\section{Task 2: Sentence translation}

1. Por favor devuélveme las llaves tan pronto como sea posible.

2. Quiero que bailes conmigo esta noche.

3. ¿Le molesta si fumo?

4. Por la presente te invito a mi fiesta el próximo sábado a las ocho de la noche. Confirma asistencia por favor.

5. Dile a tu hermana que la estoy esperando.

6. Si estuvieras conmigo yo sería más feliz.

7. Ojala tuviera más tiempo para estudiar.

8. Si me hubiera puesto el cinturón de seguridad no me habría lastimado.

9. Ella dijo que iba a venir. 
10. Report what Angela said:

Angela: "The meeting was at 5:00 and you were late." Angela said...

\section{Task 3: Picture description}
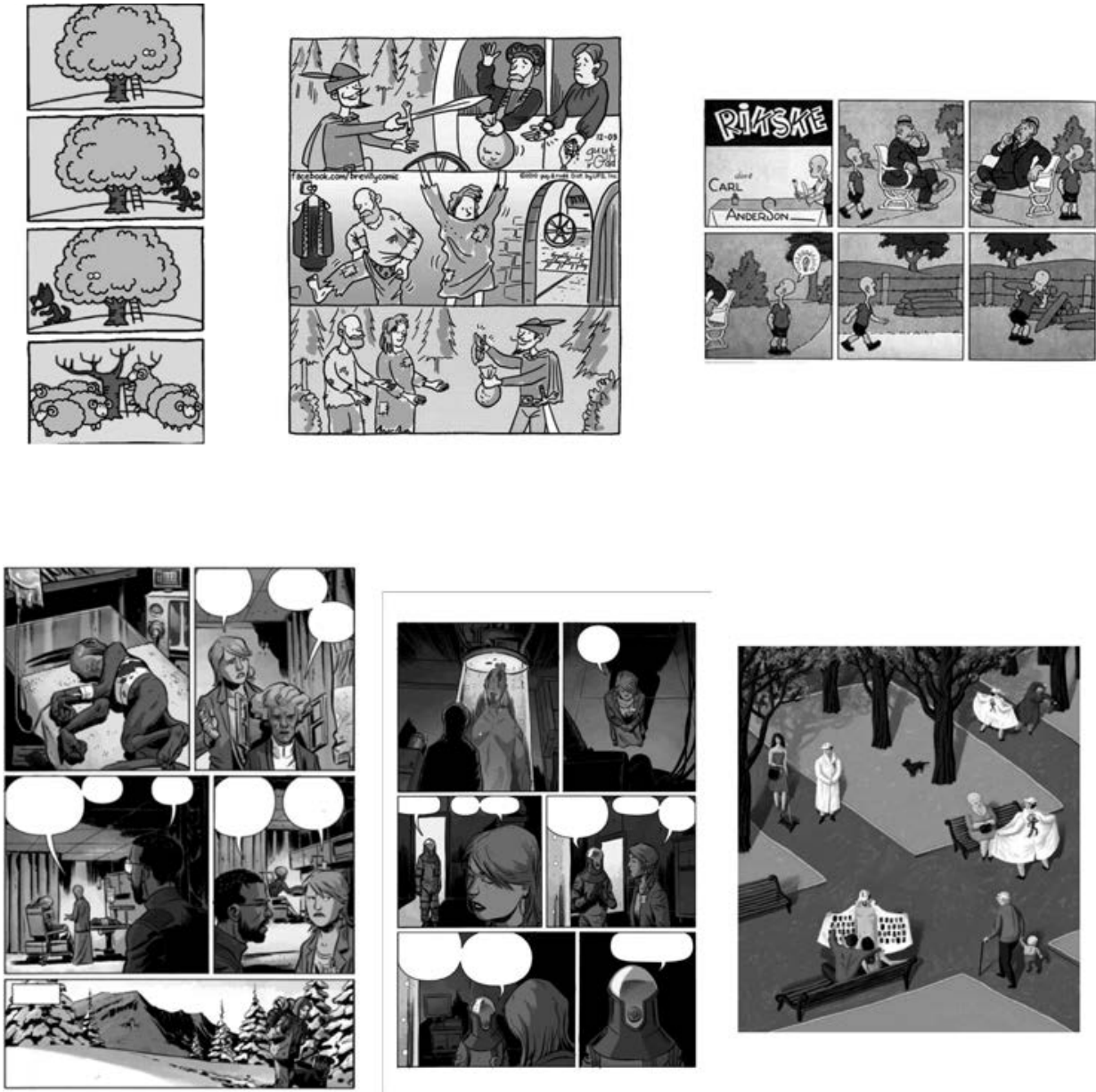